\title{
Endometrial Cancer: Comparison of Patients with Synchronous Primary Carcinoma of the Endometrium and Ovary vs. Endometrial Carcinoma with Ovarian Metastases
}

\author{
Primäres simultanes Endometrium- und Ovarialkarzinom \\ vs. Endometriumkarzinom mit Ovarialmetastasen
}

Authors

Affiliations
I. Juhasz-Böss ${ }^{1}$, T. Fehm² ${ }^{2}$ S. Becker ${ }^{4}$, R. Rothmund ${ }^{2}$, B. Krämer ${ }^{2}$, A. Staebler ${ }^{3}$, D. Wallwiener ${ }^{2}$, E. F. Solomayer ${ }^{1}$

${ }^{1}$ Klinik für Frauenheilkunde, Geburtshilfe und Reproduktionsmedizin, Universitätsklinikum des Saarlandes, Homburg/Saar

2 Universitätsfrauenklinik Tübingen, Tübingen

${ }^{3}$ Institut für Pathologie, Universität Tübingen, Tübingen

${ }^{4}$ Klinik für Frauenheilkunde und Geburtshilfe, Universitätsklinik Frankfurt, Frankfurt

\section{Key words}

- synchronous carcinomas

- endometrial cancer

- ovarian cancer

- ovarian metastases

outcome

Schlüsselwörter

- simultanes Karzinom

- Endometriumkarzinom

- Ovarialkarzinom

- Ovarialmetastasen

- Outcome

\section{Abstract}

\section{$\nabla$}

Purpose: The aim of our study was to investigate the rate of secondary carcinomas in patients with endometrial carcinoma (EC). In particular, we wanted to describe the subset of patients with endometrial and simultaneous ovarian carcinoma (OC), including outcomes. The study also compared patients with EC and ovarian metastasis with patients with EC and simultaneous OC. Patients and Methods: Data from 251 patients with primary endometrial carcinoma who underwent surgery in the years 2005-2009 at the Department of Obstetrics and Gynaecology, University of Tübingen, were analysed retrospectively.

Results: A total of 28 patients $(11.1 \%)$ had a secondary carcinoma: 18 patients (7.1\%) had OC; 9 (3.5\%) patients had a history of breast cancer, and one patient $(0.4 \%)$ respectively had simultaneous carcinoma of the vulva or bladder. 14 patients (5.5\%) had advanced stage EC with ovarian metastasis or, in one case, metastasis to the ovarian tube. Patients with ovarian metastasis had a mean age of $71.2 \pm 9.2$ years at primary diagnosis, making them significantly older compared to patients with EC and simultaneous OC (55.3 \pm 11.8 years, $\mathrm{p}<0.001$ ). Moreover, patients with ovarian metastasis significantly more often had EC with a higher tumour grade (grade 1: 0 , grade $2: 21.4 \%$, grade $3: 78.6 \%$ ) compared to patients with simultaneous EC and OC (grade 1: $11.1 \%$, grade 2: $77.8 \%$, grade 3: $11.1 \%$; $<0.001)$.

Conclusion: Almost one in 10 patients with EC had a secondary carcinoma. The most common secondary carcinoma was OC followed by breast cancer. This should be taken into account in the diagnosis and therapy of patients with EC. Patients with simultaneous EC and OC were significantly younger than patients with EC and ovarian metastasis. In addition, their tumour had better prognostic features: thus, the tumour grade of the EC was significantly lower. Overall, the prog-

\section{Zusammenfassung \\ $\nabla$}

Hintergrund: Ziel unserer Arbeit ist es, die Rate an Zweitkarzinomen bei Patientinnen mit Endometriumkarzinom (EC) zu untersuchen. Insbesondere möchten wir die Untergruppe von Patientinnen mit simultanem Endometrium- und Ovarialkarzinom (OC) inklusive Outcome beschreiben. Zudem soll diese Arbeit auch Patientinnen mit einem EC mit Ovarialmetastasen mit Patientinnen mit einem EC und simultanem OC vergleichen.

Patienten und Methode: Daten von insgesamt 251 Patientinnen mit einem primären Endometriumkarzinom, die im Zeitraum 2005-2009 an der Universitätsfrauenklinik Tübingen behandelt worden sind, wurden retrospektiv untersucht.

Ergebnisse: Insgesamt 28 Patientinnen $(11,1 \%)$ hatten ein Zweitkarzinom: 18 Patientinnen $(7,1 \%)$ hatten ein OC, 9 (3,5\%) Patientinnen hatten anamnestisch ein Mammakarzinom und jeweils eine Patientin $(0,4 \%)$ hatte simultan ein Vulvabzw. Blasenkarzinom. 14 Patientinnen (5,5\%) hatten ein fortgeschrittenes EC mit Metastasierung im Ovar bzw. in einem Fall in der Tube. Patientinnen mit Metastasen im Ovar sind bei Erstdiagnose mit durchschnittlich 71,2 $\pm 9,2$ Jahren signifikant älter als Patientinnen mit EC und simultanem OC (55,3 $\pm 11,8$ Jahre, $\mathrm{p}<0,001)$. Patientinnen mit Ovarialmetastasen haben zudem signifikant häufiger ein EC mit höherem Grading (Grading 1: 0, Grading 2: 21,4\% bzw. Grading 3: 78,6\%) als Patientinnen mit simultanem EC und OC (Grading 1: $11,1 \%$, Grading 2: $77,8 \%$ bzw. Grading 3: $11,1 \%$; $\mathrm{p}<0.001$ ).

Schlussfolgerung: Nahezu jede 10. Patientin mit EC hat ein Zweitkarzinom, wobei das häufigste Zweitkarzinom ein OC gefolgt vom Mammakarzinom ist. Dies sollte bei der Diagnostik bzw. der Therapie von Patientinnen mit EC mitberücksichtigt werden. Patientinnen mit einem simultanen EC und OC sind signifikant jünger als Patientin- 
nosis for patients with synchronous EC and $\mathrm{OC}$ is better than that for patients with EC and ovarian metastasis. nen mit einem EC und Ovarialmetastasen. Daneben weist ihr Tumor deutlich bessere prognostische Eigenschaften auf, so. z. B. ein signifikant niedrigeres Tumor-Grading des EC. Insgesamt ist die Prognose von Patientinnen mit simultanem EC und OC besser als bei EC und Ovarialmetastasen.

\section{Introduction}

$\nabla$

Endometrial carcinoma (EC) has an incidence of between 9.9 and 15.0 for every 100000 women in the western world, making it the most common genital cancer in women. Peak onset of disease is between the ages of 75 and 80 years, and the mean 5-year survival rate in countries with the highest incidence is between 72 and $84 \%[1,2]$. When taking a decision to treat it is necessary to consider the tumour stage, the patient's general state of health, and the risk factors $[1,3]$. Surgery is the treatment of choice for primary cancer and should be done where possible. After the histological diagnosis has been confirmed, FIGO classification [4] prescribes operative staging, requiring exploration of the abdomen with hysterectomy and bilateral adnexectomy [1]. Depending on the histology (i.e. tumour grade, extent of myometrial infiltration), pelvic and paraaortal lymphadenectomy or omentectomy, appendectomy or the removal of diseased organs may be necessary.

Patients with EC may simultaneously present with a secondary carcinoma. The most common secondary tumours are genital carcinomas.

\section{Simultaneous endometrial and ovarian cancer}

The rate of simultaneous ovarian carcinoma (OC) in patients with endometrial cancer is between 3.3 and 10\% [5-7]. The rate for patients with primary OC and a secondary carcinoma is less than $3 \%$ [8]. $2.7 \%$ of patients with primary OC have simultaneous EC [8].

\section{Endometrial carcinoma with ovarian metastasis}

There are still no clear histological and surgical criteria which would indicate whether the disease represents simultaneous malignant degeneration of the endometrium and the ovary or whether it represents an EC which has metastasised to the ovary or an $\mathrm{OC}$ which has metastasised to the endometrium. Because of this uncertainty the treatment offered by clinics/institutions varies and the prognosis is thus unclear. To date, information on this topic consists largely of retrospective case series with limited numbers of cases.

Recent studies have focussed on differentiating between primary EC and simultaneous OC and EC with ovarian metastasis. One important criterion proposed for the determination of primary EC with ovarian metastasis is multinodular ovarian involvement ("major criterion"), but the criteria have not yet been validated. Further indications are the presence of 2 or more "minor criteria", i.e. bilateral ovarian involvement, small ovaries $(<5 \mathrm{~cm})$, deep myometrial infiltration, vascular invasion or tubal involvement [9-11]. However, these criteria may also be present with primary EC and simultaneous OC, making differentiation often difficult. Attempts to find molecular and immunohistochemical markers which would permit a better differentiation have had only limited success. Studies on molecular parameters only investigated small numbers of cases, and immunohistochemical studies often showed similar results $[9,12]$. This continues to complicate attempts to differentiate between primary EC and primary $\mathrm{OC}$ or EC which has metastasised to the ovary. While the immunohistochemical detection of oestrogen receptor (ER), progesterone receptor (PR) and bcl-2 expression differs significantly between patients with primary EC and simultaneous OC compared to their expression in patients with EC metastasised to the ovary, parameters such as Her2Neu, Ki-67 and p53 are not suitable for any differentiation between these subgroups [9]. The most recent studies have proposed the use of additional factors such as PTEN, KRAS and $\beta$-catenin to differentiate between the tumour entities [13-15].

Patients with primary EC and OC have a better prognosis than patients with primary OC [8]. The outcome of these patients is also better compared to patients with advanced EC and ovarian metastasis [16]. It is therefore clinically relevant to know whether patients have EC with simultaneous OC or EC with ovarian metastasis [17].

The aim of our study was to investigate the rate of secondary cancers in patients with EC. In particular, we wanted to describe the subset of patients with simultaneous EC and ovarian carcinoma in more detail, including their oncological outcome. The study also aimed to compare patients with EC and ovarian metastasis and patients with simultaneous EC and OC. An overview of the current literature on this topic is given below.

\section{Patients and Method \\ $\nabla$}

Retrospective analysis was done of all patients with primary EC who underwent surgery in the years 2005-2009 at the Department of Obstetrics and Gynaecology, University of Tübingen.

All patients with a histological diagnosis of EC were included in our study. The study also investigated any history of secondary carcinoma or diagnosis of secondary carcinoma found during treatment for EC.

The following characteristics were recorded and analysed for all patients: age at primary diagnosis of EC, initial FIGO stage, infiltration of the myometrium, tumour grade, lymph node status, intraoperative cytology, number and localisation of distant intraabdominal metasases, and recurrence or date of death.

All patients underwent surgery based on their tumour stage with hysterectomy, bilateral salpingo-oophorectomy and pelvic and paraaortal lymphadenectomy. Patients with advanced EC or simultaneous OC additionally had omentectomy with multiple peritoneal biopsies and appendectomy, where necessary.

Postoperatively all patients were discussed in an interdisciplinary tumour conference. Depending on the tumour stage, surgery was followed by brachytherapy and/or teletherapy or chemotherapy. All patients were regularly followed up at the clinic or by their gynaecologist.

Statistical analysis was done using SPSS 15.0 for Windows (SPSS Inc., Chicago, IL, USA). P $<0.05$ was considered statistically significant. 


\section{Results}

$\nabla$

\section{Patient population}

The data of 251 patients with primary EC who underwent surgery, depending on tumour stage, in the years 2005-2009 at the Department of Obstetrics and Gynaecology, University of Tübingen, were retrospectively analysed. Patient and tumour characteristics are given in $\bullet$ Table 1.

\section{Secondary carcinoma}

A total of 28 patients (11.1\%) had secondary cancer in addition to EC: 18 patients $(7.1 \%)$ had OC, 9 patients $(3.5 \%)$ had a history of breast cancer and one patient $(0.4 \%)$ respectively had simultaneous vulva or bladder cancer. The patient with bladder cancer had an additional history of breast cancer. The data of these 28 patients including information on their tumours and outcomes is summarised in $\bullet$ Table 2.

\section{Comparison of EC with ovarian metastasis and $\mathrm{EC}$ with $\mathrm{OC}$}

Out of a total of 251 patients, 14 patients (5.5\%) had advanced EC with ovarian metastasis or, in one case, metastasis to the ovarian tube. These patients were compared with the 18 patients with simultaneous OC. Patients with advanced EC but without ovarian metastasis (e.g. only peritoneal metastasis or distant metastases, i.e. stage T3b or T4) were not included in the comparison. At primary diagnosis patients with ovarian metastases were significantly older (mean age $71.2 \pm 9.2$ years) than patients with EC and simultaneous OC $(55.3 \pm 11.8$ years, $\mathrm{p}<0.001)$. Moreover, patients with ovarian metastasis significantly more often had higher grade EC (grade 1: 0 , grade $2: 21.4 \%$, grade $3: 78.6 \%$ ) than patients with simultaneous EC and OC (grade 1: $11.1 \%$, grade 2 : $77.8 \%$, grade $3: 11.1 \% ; \mathrm{p}<0.001$ ). The data of these two subsets including myometrial infiltration, lymph node involvement, cytology, histology findings, and oncological outcome is summarised in $\odot$ Table 3.

\section{Discussion}

\section{$\nabla$}

Our patient population consisted of a total of 251 patients with EC, of which 18 patients had simultaneous OC and 14 patients had EC with ovarian metastasis. We thus investigated a relatively large patient population; most comparable studies had similarly large populations or patient populations of up to 100 patients [5, $6,9,16]$.

The mean age of all EC patients in our patient population was 62.3 years. Patients in our population with EC which had metastasised to the ovary were significantly younger with a mean age of 55.3 years compared to patients with primary EC and OC (mean age 71.2 years). Nishimura et al. reported similar findings with a significant difference in age between the two groups: patients with simultaneous EC and OC were significantly younger (45.2 vs. 51.2 years). It should be noted, however, that overall the patients in their study were younger than our patient population [16]. The mean age of patients with simultaneous EC and OC or EC with ovarian metastasis without differentiating between the two groups is generally reported to be 49-51 years $[6,7,9] .51 \%$ of patients with simultaneous EC and OC were premenopausal and 33\% were nulliparous [6].

Almost $81 \%$ of patients in our total patient population had an endometrioid EC. When we examined patients with simultaneous
Table 1 Patient characteristics (EC = endometrial carcinoma).

\begin{tabular}{|c|c|}
\hline Parameter & Value \\
\hline Number of patients with EC (total) & 251 \\
\hline Age at first diagnosis of EC (years) & $62.3 \pm 11.8$ \\
\hline $\begin{array}{l}\text { Number of patients with secondary cancer } \\
\text { (total) }\end{array}$ & 29 \\
\hline Ovary & 18 \\
\hline Breast & 9 \\
\hline Vulva & 1 \\
\hline Bladder & 1 \\
\hline \multicolumn{2}{|l|}{ Tumour stage } \\
\hline I & $208(83.8 \%)$ \\
\hline II & $14(5.6 \%)$ \\
\hline III & $23(9.3 \%)$ \\
\hline IV & $3(1.2 \%)$ \\
\hline \multicolumn{2}{|l|}{ Infiltration of the myometrium } \\
\hline None & $37(14.7 \%)$ \\
\hline$<50 \%$ & $138(55.0 \%)$ \\
\hline$>50 \%$ & $61(24.3 \%)$ \\
\hline Serosal involvement & $7(2.8 \%)$ \\
\hline Unknown & $8(3.2 \%)$ \\
\hline \multicolumn{2}{|l|}{ Tumour grade } \\
\hline 1 & $44(17.5 \%)$ \\
\hline 2 & $159(63.3 \%)$ \\
\hline 3 & $48(19.1 \%)$ \\
\hline \multicolumn{2}{|l|}{ Cytology } \\
\hline Negative & $91.7 \%$ \\
\hline Positive & $8.3 \%$ \\
\hline \multicolumn{2}{|l|}{ Histotype } \\
\hline Endometrioid & $203(80.9 \%)$ \\
\hline Non-endometrioid & $48(19.1 \%)$ \\
\hline papillary & 9 \\
\hline - tubal & 8 \\
\hline serous & 6 \\
\hline tubulopapillary & 3 \\
\hline adenosquamous & 3 \\
\hline - eccrine & 3 \\
\hline - clear cell & 1 \\
\hline - squamous epithelial carcinoma & 1 \\
\hline $\begin{array}{l}\text { adenocarcinoma without } \\
\text { further specifications }\end{array}$ & 14 \\
\hline Follow-up (months) & $20.4 \pm 14.7$ (range $0-50$ ) \\
\hline \multicolumn{2}{|l|}{ Outcome } \\
\hline alive & 210 \\
\hline - recurrence & 16 \\
\hline D died & 25 \\
\hline
\end{tabular}

EC and OC, the numbers for patients with endometrioid carcinoma were similar (77.8\%). In the prospective study by Zaino et al., the numbers of patients (86\%) with endometrioid carcinoma of the endometrium and ovary were similar to those in our study [7]. However, some studies have reported lower rates. Soliman et al. reported that only $68 \%$ of patients with either EC or OC had an endometrioid histology [6]. The rate reported by Williams et al. was even lower: in patients with simultaneous EC and OC, only $59.6 \%$ of EC and $58.1 \%$ of OC were endometrioid carcinomas [8]. The importance aspect of this study is that it evaluated the data of a total of 56986 patients. The rate of endometrioid carcinomas in patients with only OC (= single ovarian cancer) was significantly lower with $10.6 \%$ [8].

When we studied our patients with EC and ovarian metastasis, only $64.3 \%$ had an endometrioid carcinoma. This difference was not significant compared to patients with simultaneous EC and 
Table 2 Details of patients with endometrial carcinoma and known secondary carcinoma (EC $=$ endometrial carcinoma, $-=$ negative, $+=$ positive, $x=u n k n o w n)$

\begin{tabular}{|c|c|c|c|c|c|c|c|c|c|}
\hline Patient & $\begin{array}{l}\text { Age } \\
\text { (years) }\end{array}$ & Histotype EC & Grade & $\begin{array}{l}\text { Myometrial } \\
\text { infiltration }\end{array}$ & $\begin{array}{l}\text { Lymph node } \\
\text { involvement }\end{array}$ & Cytology & $\begin{array}{l}\text { Secondary } \\
\text { carcinoma }\end{array}$ & $\begin{array}{l}\text { Follow-up } \\
\text { (months) }\end{array}$ & Outcome \\
\hline 1 & 71 & $\begin{array}{l}\text { endometrioid } \\
\text { adenocarcinoma }\end{array}$ & 2 & $<50 \%$ & - & - & breast & 49 & alive \\
\hline 2 & 51 & $\begin{array}{l}\text { tubal } \\
\text { adenocarcinoma }\end{array}$ & 2 & $<50 \%$ & - & - & breast & 45 & alive \\
\hline 3 & 59 & $\begin{array}{l}\text { tubal } \\
\text { adenocarcinoma }\end{array}$ & 2 & $<50 \%$ & - & - & ovary & 43 & alive \\
\hline 4 & 57 & $\begin{array}{l}\text { endometrioid } \\
\text { adenocarcinoma }\end{array}$ & 2 & $<50 \%$ & - & - & ovary & 43 & alive \\
\hline 5 & 64 & $\begin{array}{l}\text { endometrioid } \\
\text { adenocarcinoma }\end{array}$ & 2 & $<50 \%$ & - & - & breast & 43 & alive \\
\hline 6 & 63 & $\begin{array}{l}\text { tubal } \\
\text { adenocarcinoma }\end{array}$ & 2 & $<50 \%$ & $\mathrm{x}$ & + & ovary & 4 & died \\
\hline 7 & 46 & $\begin{array}{l}\text { tubal } \\
\text { adenocarcinoma }\end{array}$ & 2 & $>50 \%$ & - & - & ovary & 41 & alive \\
\hline 8 & 53 & $\begin{array}{l}\text { endometrioid } \\
\text { adenocarcinoma }\end{array}$ & 2 & $<50 \%$ & - & + & ovary & 39 & alive \\
\hline 9 & 44 & $\begin{array}{l}\text { endometrioid } \\
\text { adenocarcinoma }\end{array}$ & 2 & $<50 \%$ & $\mathrm{x}$ & + & ovary & 37 & $\begin{array}{l}\text { recur- } \\
\text { rence }\end{array}$ \\
\hline 10 & 64 & $\begin{array}{l}\text { endometrioid } \\
\text { adenocarcinoma }\end{array}$ & 2 & $>50 \%$ & - & - & vulva & 36 & died \\
\hline 11 & 59 & $\begin{array}{l}\text { endometrioid } \\
\text { adenocarcinoma }\end{array}$ & 2 & $\begin{array}{l}\text { serosa } \\
\text { Involvement }\end{array}$ & $x$ & + & ovary & 1 & alive \\
\hline 12 & 85 & $\begin{array}{l}\text { endometrioid } \\
\text { adenocarcinoma }\end{array}$ & 3 & $>50 \%$ & $\mathrm{x}$ & $\mathrm{x}$ & ovary & 0 & alive \\
\hline 13 & 65 & $\begin{array}{l}\text { papillary } \\
\text { adenocarcinoma }\end{array}$ & 2 & $<50 \%$ & - & $\mathrm{x}$ & breast & 29 & $\begin{array}{l}\text { recur- } \\
\text { rence }\end{array}$ \\
\hline 14 & 63 & $\begin{array}{l}\text { endometrioid } \\
\text { adenocarcinoma }\end{array}$ & 2 & $<50 \%$ & - & - & breast & 27 & alive \\
\hline 15 & 38 & $\begin{array}{l}\text { endometrioid } \\
\text { adenocarcinoma }\end{array}$ & 2 & $<50 \%$ & + & $x$ & ovary & 0 & alive \\
\hline 16 & 63 & $\begin{array}{l}\text { endometrioid } \\
\text { adenocarcinoma }\end{array}$ & 2 & none & + & + & ovary & 26 & died \\
\hline 17 & 44 & $\begin{array}{l}\text { endometrioid } \\
\text { adenocarcinoma }\end{array}$ & 2 & $<50 \%$ & - & - & ovary & 24 & alive \\
\hline 18 & 55 & $\begin{array}{l}\text { endometrioid } \\
\text { adenocarcinoma }\end{array}$ & 2 & $<50 \%$ & - & - & breast & 24 & $\begin{array}{l}\text { recur- } \\
\text { rence }\end{array}$ \\
\hline 19 & 57 & $\begin{array}{l}\text { endometrioid } \\
\text { adenocarcinoma }\end{array}$ & 1 & none & - & - & ovary & 22 & alive \\
\hline 20 & 52 & $\begin{array}{l}\text { endometrioid } \\
\text { adenocarcinoma }\end{array}$ & 2 & $<50 \%$ & - & + & ovary & 20 & alive \\
\hline 21 & 71 & $\begin{array}{l}\text { tubal } \\
\text { adenocarcinoma }\end{array}$ & 2 & $>50 \%$ & $x$ & - & ovary & 1 & died \\
\hline 22 & 52 & $\begin{array}{l}\text { endometrioid } \\
\text { adenocarcinoma }\end{array}$ & 2 & $>50 \%$ & - & - & ovary & 16 & alive \\
\hline 23 & 67 & $\begin{array}{l}\text { endometrioid } \\
\text { adenocarcinoma }\end{array}$ & 3 & $<50 \%$ & - & + & ovary & 14 & alive \\
\hline 24 & 42 & $\begin{array}{l}\text { endometrioid } \\
\text { adenocarcinoma }\end{array}$ & 2 & none & - & - & ovary & 14 & alive \\
\hline 25 & 77 & $\begin{array}{l}\text { endometrioid } \\
\text { adenocarcinoma }\end{array}$ & 3 & $>50 \%$ & + & + & breast & 9 & alive \\
\hline 26 & 65 & $\begin{array}{l}\text { endometrioid } \\
\text { adenocarcinoma }\end{array}$ & 1 & $<50 \%$ & - & - & breast & 7 & alive \\
\hline 27 & 45 & $\begin{array}{l}\text { endometrioid } \\
\text { adenocarcinoma }\end{array}$ & 1 & $<50 \%$ & - & - & ovary & 7 & alive \\
\hline 28 & 74 & $\begin{array}{l}\text { endometrioid } \\
\text { adenocarcinoma }\end{array}$ & 3 & $x$ & $x$ & $x$ & $\begin{array}{l}\text { breast + } \\
\text { bladder }\end{array}$ & 6 & $\begin{array}{l}\text { recur- } \\
\text { rence }\end{array}$ \\
\hline
\end{tabular}

OC but it is worth considering whether this was the reason for the somewhat poorer prognosis for this subgroup in our study. Chiang et al. reported similar findings. In their study, the mean survival time for patients with the same histology $(n=15)$ was 63 months compared to 48 months for patients with differing histological findings $(n=12)[5]$. Soliman et al. could even show that patients with a concordant endometrioid histology had a significantly better prognosis: patients with a concordant endometrioid histology had a mean survival time of 119 months, which was significantly higher than that for all other groups [6]. 
The most recent investigations into the pathogenesis of ovarian carcinoma indicate that these tumours originate in the tubal fimbria [18]. An early carcinoma was found in approx. $5 \%$ of adnexa investigated after resection for prophylactic reasons in women with BRCA1 or BRCA2 mutation, and $80 \%$ of these originated in the fimbria as serous tubal intraepithelial carcinoma [19]. It is not clear whether serous ovarian or peritoneal carcinomas without proven BRCA mutation also have a tubal origin. Even if we assume that the carcinoma has originated in the tube we would like to note here, with regard to our study, that in our patient population the majority of patients had an endometrioid carcinoma, both the group of patients with ovarian metastasis and the group with ovarian carcinoma.

Tumour grade is another important prognostic parameter [20]. In our study, patients with an EC which had metastasised to the ovary had a significantly higher tumour grade than patients with simultaneous EC and OC.

The majority of our patients (77\%) with simultaneous EC and OC had a grade 2 tumour; only $11 \%$ had a grade 3 or grade 1 EC tumour. Zaino et al. reported that $51 \%$ of EC and OC tumours in their patient population were grade 1 [7]. However, other studies have described lower rates of grade 1 tumours; thus, in another retrospective study of 29 patients also by Zaino et al., they reported a rate of only $30 \%$ [21], and Eifel et al. described a rate of $56 \%[22]$.

When we studied our patients with EC and ovarian metastasis, $78.6 \%$ of patients had a grade 3 EC tumour and only $21.4 \%$ had a grade 2 tumour; there were no patients with a grade 1 tumour. This significantly higher rate of higher grade tumours (G2 and G3) could also be responsible for the higher rates of recurrence and death for this subgroup ( Table 3 ). Similar to our findings, Zaino et al. described an increased risk of recurrence for patients with grade 2 or grade 3 tumours compared to grade 1 tumours [7]. Patients with a grade 1 tumour in both the endometrium and the ovary had a significantly lower 5-year rate of recurrence compared to patients with at least one tumour above grade 1 ( 8 vs. $22.4 \%$ ) [7].

The rate of recurrence also depends on the extent of myometrial infiltration. $77 \%$ of patients with deep myometrial infiltration had recurrence or died [7]. In our patient population, $72.3 \%$ patients with simultaneous EC and OC either had no myometrial infiltration or the myometrial infiltration was $<50 \%$. In the literature some authors report that up to $100 \%$ of patients had no myometrial infiltration or infiltration of $<50 \%[23,24]$. As expected, patients with advanced EC and ovarian metastasis are more likely to have deeper myometrial infiltration. In our patient population, $21.4 \%$ of these patients even had serosal involvement. The results of Nishimura et al. were similar to ours. Here too, the two subgroups did not differ significantly with regard to myometrial infiltration; however, it was very noticeable that patients with an EC which had metastasised to the ovary were more likely to have myometrial infiltration $>50 \%$ compared to patients with simultaneous EC and OC (48 vs. 0\%) [16].

All of the criteria described above such as histological type, tumour grade, extent of myometrial infiltration and thus tumour stage are relevant for patients with simultaneous EC and OC and for patients with EC and ovarian metastasis [5]. Patients with disease limited to the uterus and the ovaries had a 5-year recurrence rate of $10 \%$ compared to $27 \%$ for patients who already had metastasis at the time of surgery [7].

It is notable that most studies reported a relatively good prognosis for patients with simultaneous EC and OC compared to pa-
Table 3 Comparison of patients with endometrial carcinoma and ovarian metastasis vs. endometrial carcinoma with simultaneous ovarian carcinoma (mean \pm standard deviation).

\begin{tabular}{|c|c|c|c|}
\hline Parameter & $\begin{array}{l}\text { Ovarian me- } \\
\text { tastasis }\end{array}$ & $\begin{array}{l}\text { Simulta- } \\
\text { neous ovar- } \\
\text { ian cancer }\end{array}$ & $\mathbf{P}$ \\
\hline $\begin{array}{l}\text { Total number } \\
\text { of patients }\end{array}$ & 14 & 18 & \\
\hline $\begin{array}{l}\text { Age at primary } \\
\text { diagnosis (years) }\end{array}$ & $71.2 \pm 9.2$ & $55.3 \pm 11.8$ & $<0.001$ \\
\hline Myometrial infiltration & & & n.s. \\
\hline none & $3(21.4 \%)$ & $3(16.7 \%)$ & \\
\hline$<<50 \%$ & $4(28.6 \%)$ & $10(55.6 \%)$ & \\
\hline$>>50 \%$ & $3(21.4 \%)$ & $4(22.2 \%)$ & \\
\hline - serosal involvement & $3(21.4 \%)$ & $1(5.6 \%)$ & \\
\hline unknown & $1(7.1 \%)$ & 0 & \\
\hline Tumour grade & & & $<0.001$ \\
\hline 1 & 0 & $2(11.1 \%)$ & \\
\hline$>2$ & $3(21.4 \%)$ & $14(77.8 \%)$ & \\
\hline$>3$ & $11(78.6 \%)$ & $2(11.1 \%)$ & \\
\hline $\begin{array}{l}\text { Lymph node } \\
\text { involvement }\end{array}$ & & & n.s. \\
\hline negative & $8(57.1 \%)$ & $11(61.1 \%)$ & \\
\hline positive & $6(42.9 \%)$ & $2(11.1 \%)$ & \\
\hline - unknown & 0 & $5(27.8 \%)$ & \\
\hline Cytology & & & n.s. \\
\hline negative & $7(50 \%)$ & $9(50 \%)$ & \\
\hline positive & $5(35.7 \%)$ & $7(38.9 \%)$ & \\
\hline - unknown & $2(14.3 \%)$ & $2(11.1 \%)$ & \\
\hline Histotype & & & n.s. \\
\hline $\begin{array}{l}\text { - endometrioid } \\
\text { adenocarcinoma }\end{array}$ & $9(64.3 \%)$ & $14(77.8 \%)$ & \\
\hline $\begin{array}{l}\text { tubal } \\
\text { adenocarcinoma }\end{array}$ & - & $4(22.2 \%)$ & \\
\hline $\begin{array}{l}\text { eccrine } \\
\text { adenocarcinoma }\end{array}$ & $3(21.4 \%)$ & - & \\
\hline $\begin{array}{l}\text { serous } \\
\text { adenocarcinoma }\end{array}$ & $2(14.3 \%)$ & - & \\
\hline Follow-up (months) & $\begin{array}{l}13.4 \pm 16.2 \\
\text { (range } 0-50 \text { ) }\end{array}$ & $\begin{array}{l}19.5 \pm 15.7 \\
\text { (range } 0-43 \text { ) }\end{array}$ & n.s. \\
\hline Outcome & & & n.s. \\
\hline alive & $6(42.8 \%)$ & $14(77.7 \%)$ & \\
\hline - recurrence & $2(14.3 \%)$ & $1(5.5 \%)$ & \\
\hline died & $6(42.8 \%)$ & $3(16.6 \%)$ & \\
\hline
\end{tabular}

tients with EC and ovarian metastasis. In what is to our knowledge currently still the only prospective investigation by Zaino et al., patients with simultaneous EC and OC had a 5-year survival rate of $85.9 \%$ and a 10 -year survival rate of $80.3 \%$ [7]. Nishimura et al. reported similar survival rates. The 10 -year survival rate for patients with simultaneous EC and OC was significantly better than that for the group of patients with metastasis (90.9 vs. $46.6 \%$ ) [16]. In our patient population, $77.7 \%$ of patients with simultaneous EC and OC also had no recurrence, while only $42.8 \%$ of patients with EC and ovarian metastasis had no recurrence. In summary, we could show that almost one in 10 patients with an EC had a secondary carcinoma. The most common secondary carcinoma was an OC, followed by breast cancer. This should be taken into account in the diagnosis and therapy of patients with EC. Patients with simultaneous EC and OC were significantly younger than patients with an EC and ovarian metastasis. Their tumours also had significantly better prognostic features; thus, the tumour grades for EC were significantly lower. Overall, the 
prognosis for patients with simultaneous EC and OC was significantly better than that for patients with EC and ovarian metastasis.

\section{Conclusion}

$\nabla$

Almost one in ten patients with an endometrial carcinoma (EC) had a secondary carcinoma. The most common secondary carcinoma was ovarian carcinoma (OC), followed by breast cancer. This needs to be taken into account in the diagnosis and therapy of patients with EC. Patients with simultaneous EC and OC have a significantly better prognosis than patients with advanced EC and ovarian metastasis.

\section{Conflict of Interest}

The authors declare that they have no financial relationship with any company relevant for this article.

\section{References}

1 AGO, DKG, DGGG. Diagnostik und Therapie des Endometriumkarzinoms. Interdisziplinäre S2-Leitlinie, AWMF 032/034

2 Hartkopf $A D$, Fehm T, Wallwiener $M$ et al. Oncolytic viruses to treat ovarian cancer patients - a review of results from clinical trials. Geburtsh Frauenheilk 2012; 72: 132-136

3 Marnitz-Schulze S. Onkologie. Adjuvante Radiotherapie des Endometriumkarzinoms. Geburtsh Frauenheilk 2012; 72: 19-23

4 Petru E. Neuerungen beim FIGO-Staging gynäkologischer Malignome 2009. Geburtsh Frauenheilk 2010; 70: 269-272

5 Chiang YC, Chen CA, Huang CY et al. Synchronous primary cancers of the endometrium and ovary. Int J Gynecol Cancer 2008; 18: 159-164

6 Soliman PT, Slomovitz BM, Broaddus RR et al. Synchronous primary cancers of the endometrium and ovary: a single institution review of 84 cases. Gynecol Oncol 2004; 94: 456-462

7 Zaino R, Whitney C, Brady MF et al. Simultaneously detected endometrial and ovarian carcinomas - a prospective clinicopathologic study of 74 cases: a gynecologic oncology group study. Gynecol Oncol 2001; 83 : 355-362

8 Williams MG, Bandera EV, Demissie K et al. Synchronous primary ovarian and endometrial cancers: a population-based assessment of survival. Obstet Gynecol 2009; 113: 783-789
9 Halperin R, Zehavi S, Hadas E et al. Simultaneous carcinoma of the endometrium and ovary vs. endometrial carcinoma with ovarian metastases: a clinical and immunohistochemical determination. Int J Gynecol Cancer 2003; 13: 32-37

10 Ulbright TM, Roth LM. Metastatic and independent cancers of the endometrium and ovary: a clinicopathologic study of 34 cases. Hum Pathol 1985; $16: 28-34$

11 Scully R, Young R, Clement P. Tumors of the ovary, maldeveloped gonads, fallopian tube, and broad ligament. In: Atlas of Tumor Pathology. Washington, DC: Armed Forces Institute of Pathology; 1998: Tables 5-1-5-3

12 Prat J, Matias-Guiu X, Barreto J. Simultaneous carcinoma involving the endometrium and the ovary. A clinicopathologic, immunohistochemical, and DNA flow cytometric study of 18 cases. Cancer 1991; 68: 2455-2459

13 Chen J, Li S, Yang Z et al. Correlation between NDRG1 and PTEN expression in endometrial carcinoma. Cancer Sci 2008; 99: 706-710

14 Merritt MA, Cramer DW. Molecular pathogenesis of endometrial and ovarian cancer. Cancer Biomark 2011; 9: 287-305

15 Singh K, Simon RA, Zhang C et al. "Surface epithelial changes" in uterine endometrioid carcinoma mimicking micropapillary serous borderline tumor of ovary: report of two cases and review of the literature. Diagn Pathol 2011; 6: 13

16 Nishimura N, Hachisuga T, Nabeshima Ket al. Synchronous endometrial and ovarian carcinomas: analysis of genetic relationship of the tumors. Int J Oncol 2005; 27: 1519-1526

17 Ney JT, Fehm T, Juhasz-Boess I et al. RANK, RANKL and OPG expression in breast cancer - influence on osseous metastasis. Geburtsh Frauenheilk 2012; 72: 385-391

18 Przybycin CG, Kurman RJ, Ronnett BM et al. Are all pelvic (nonuterine) serous carcinomas of tubal origin? Am J Surg Pathol 2010; 34: 14071416

19 Callahan MJ, Crum CP, Medeiros F et al. Primary fallopian tube malignancies in BRCA-positive women undergoing surgery for ovarian cancer risk reduction. J Clin Oncol 2007; 25: 3985-3990

20 Köbel M, Löning T. Kommentar zu einem modifizierten Grading des Endometriumkarzinoms. Geburtsh Frauenheilk 2011; 71: 954-955

21 Zaino RJ, Unger ER, Whitney C. Synchronous carcinomas of the uterine corpus and ovary. Gynecol Oncol 1984; 19: 329-335

22 Eifel P, Hendrickson M, Ross J et al. Simultaneous presentation of carcinoma involving the ovary and the uterine corpus. Cancer 1982; 50: 163-170

23 Sheu BC, Lin HH, Chen CK et al. Synchronous primary carcinomas of the endometrium and ovary. Int J Gynaecol Obstet 1995; 51: 141-146

24 Ma SK, Zhang HT, Sun YC et al. Synchronous primary cancers of the endometrium and ovary: review of 43 cases. Zhonghua Zhong Liu Za Zhi [Chinese journal of oncology] 2008;30: 690-694

Deutschsprachige Zusatzinformationen online abrufbar unter: www.thieme-connect.de/ejournals/toc/gebfra. 